TITLE:

\title{
Evaluation of Electrode Overpotentials on Yttrium-Doped Barium Zirconate Electrolyte by Current Interruption Using Three- Electrode Cell
}

\section{$\operatorname{AUTHOR}(\mathrm{S})$ :}

Onishi, T.; Han, D.; Hatada, N.; Noda, Y.; Adachi, Y.; Majima, M.; Uda, T.

\section{CITATION:}

Onishi, T.... [et al]. Evaluation of Electrode Overpotentials on Yttrium-Doped Barium Zirconate Electrolyte by Current Interruption Using Three-Electrode Cell. Journal of the Electrochemical Society 2014, 162(3): F250-F257

\section{ISSUE DATE:}

2014-12-09

URL:

http://hdl.handle.net/2433/196842

\section{RIGHT:}

(c) The Author(s) 2014. Published by ECS.; This is an open access article distributed under the terms of the Creative Commons Attribution Non-Commercial No Derivatives 4.0 License (CC BY-NC-ND,

http://creativecommons.org/licenses/by-nc-nd/4.0//, which permits non-commercial reuse, distribution, and reproduction in any medium, provided the original work is not changed in any way and is properly cited. For permission for commercial reuse, please email: oa@electrochem.org. 


\title{
(4) \\ Evaluation of Electrode Overpotentials on Yttrium-Doped Barium Zirconate Electrolyte by Current Interruption Using Three-Electrode Cell
}

\author{
Takayuki Onishi, ${ }^{\text {a,z }}$ Donglin Han, ${ }^{\mathrm{a}}$ Naoyuki Hatada, ${ }^{\mathrm{a}}$ Yohei Noda, ${ }^{\mathrm{a}, \mathrm{b}}$ Yoshinobu Adachi, ${ }^{\mathrm{a}}$ \\ Masatoshi Majima, ${ }^{\mathrm{b}}$ and Tetsuya $\mathrm{Uda}^{\mathrm{a}, \mathrm{z}}$
}

${ }^{a}$ Department of Materials Science and Engineering, Kyoto University, Kyoto 606-8501, Japan

${ }^{b}$ Sumitomo Electric Industries, Ltd., Itami, Hyogo Prefecture 664-0016, Japan

\begin{abstract}
Yttrium-doped barium zirconate (BZY) is accepted as one of the most promising electrolyte materials for protonic ceramic fuel cells (PCFCs). For the development of fuel cells with the BZY electrolytes, evaluation of electrode performance is important. In this work, electrochemical measurements of an electrolyte supported cell, $\mathrm{Pd}\left(\right.$ wet $\left.\mathrm{H}_{2}\right)\left|\mathrm{BaZr}_{0.8} \mathrm{Y}_{0.2} \mathrm{O}_{3-\delta}\right| \mathrm{La}_{0.6} \mathrm{Sr}_{0.4} \mathrm{Co}_{0.2} \mathrm{Fe}_{0.8} \mathrm{O}_{3-\delta}($ wet $\mathrm{O}_{2}$ ), were performed at $600^{\circ} \mathrm{C}$ in a three-electrode system. The ohmic resistances of the electrolyte under open circuit condition and DC current flow were evaluated by AC impedance and current interruption measurements, respectively. Overpotentials of cathode and anode are determined to be 0.587 and $0.053 \mathrm{~V}$ at $100 \mathrm{mAcm}^{-2}$, respectively, and exhibit a logarithmic relationship with current density. The results clearly indicate that high cathode overpotential is a significant problem restricting the fuel cell performance. (C) The Author(s) 2014. Published by ECS. This is an open access article distributed under the terms of the Creative Commons Attribution Non-Commercial No Derivatives 4.0 License (CC BY-NC-ND, http://creativecommons.org/licenses/by-nc-nd/4.0/), which permits non-commercial reuse, distribution, and reproduction in any medium, provided the original work is not changed in any way and is properly cited. For permission for commercial reuse, please email: oa@electrochem.org. [DOI: 10.1149/2.0171503jes] All rights reserved.
\end{abstract}

Manuscript submitted October 14, 2014; revised manuscript received December 2, 2014. Published December 12, 2014.

Among various types of fuel cells, solid oxide fuel cells (SOFCs) have the advantages of high energy conversion efficiency and high electrode performance without Pt catalyst. In order to improve the performances of SOFCs, a precise evaluation of cathode property is essential, and several excellent works have been performed. ${ }^{1-10}$

However, the operation for SOFCs is generally higher than $800^{\circ} \mathrm{C}$, resulting in severe requirements on structural materials. In order to decrease the operation temperature, protonic ceramic fuel cells (PCFCs), which use proton conductive electrolytes, are attracting a lot of attention since they work at intermediate temperature range $\left(400-700^{\circ} \mathrm{C}\right)$.

Yttrium-doped barium zirconate, $\mathrm{BaZr}_{1-x} \mathrm{Y}_{x} \mathrm{O}_{3-\delta}$ (BZY), is accepted as one of the most promising electrolyte materials for PCFCs due to its high protonic conductivity $\left(\sim 10 \mathrm{mScm}^{-1}\right.$ at $\left.600^{\circ} \mathrm{C}\right)$ and high stability in $\mathrm{H}_{2} \mathrm{O}$ or $\mathrm{CO}_{2}$ containing atmospheres. ${ }^{11,12}$ Great concern has been focused on the performance of fuel cells, ${ }^{13-17}$ but the work on overpotential of electrode, especially cathode, with a change of current density is quite limited for the fuel cell using a BZY electrolyte, though there are several reports on the cells using acceptor doped barium cerate electrolytes. ${ }^{18-20}$

In the electrochemical measurement of the cell using a BZY electrolyte, the effect of hole conduction should be taken into concern. Under an oxidizing atmosphere, the BZY electrolyte also exhibits hole conduction, which causes quite significant influence on the symmetric cell measurement. ${ }^{21,22}$ To avoid the influence of hole conduction, it is effective to perform the measurement under fuel cell operation condition, since the hole conduction in the electrolyte is blocked at the anode side under a reducing atmosphere. In this work, the overpotential of LSCF cathode on BZY electrolyte in fuel cell operation was evaluated by a current interruption method using a three-electrode cell.

\section{Experimental}

Cell fabrication.- $\mathrm{BaZr}_{0.8} \mathrm{Y}_{0.2} \mathrm{O}_{3-\delta}$ (BZY20) powder prepared by a conventional solid state reaction method ${ }^{23}$ was mixed with an organic binder (NCB-166, DIC corporation) at a weight ratio of 7:1 using a mortar and pestle, and sieved through a $150 \mu \mathrm{m}$ mesh. The mixture was uniaxially pressed into pellets in a die with the size of $22 \mathrm{~mm}$ in diameter at $392 \mathrm{MPa}$. The pellets were then heated from room temperature to $600^{\circ} \mathrm{C}$ with a heating rate of $0.2^{\circ} \mathrm{Cmin}^{-1}$, and subsequently held at $600^{\circ} \mathrm{C}$ for $2 \mathrm{~h}$ to remove the binder. Finally, the pellets were embedded in BZY20 sacrificial powder to avoid vaporization of $\mathrm{BaO}$ during a subsequent sintering performed at $1600^{\circ} \mathrm{C}$ in $\mathrm{O}_{2}$ for $24 \mathrm{~h}$.

Both sides of the sintered pellets were mechanically polished by a rotational polishing machine (ML150-P, Maruto Instrument) with \#100-400 wet abrasive papers. After polishing, the size of the pellets was about $20 \mathrm{~mm}$ in diameter and $3 \mathrm{~mm}$ in thickness. A cathode slurry was made by mixing $\mathrm{La}_{0.6} \mathrm{Sr}_{0.4} \mathrm{Co}_{0.2} \mathrm{Fe}_{0.8} \mathrm{O}_{3-\delta}$ (LSCF, Daiichi Kigenso Kagaku Kogyo) powder, iso-propanol, toluene and dispersant (Mariarim AKM-6531, NOF corporation) in the weight ratio of $1: 1.5$ : $3: 0.01$. Such slurry was sprayed onto one side of the pellet masked by cellophane tape to obtain circular electrode with the diameter of $7 \mathrm{~mm}$, followed by heat-treatment at $1000^{\circ} \mathrm{C}$ for 2 hours in dry $\mathrm{O}_{2}$ to obtain a good adhesion of cathode/electrolyte interface. Then the cell was hydrated by heat-treating at 800,700 and $600^{\circ} \mathrm{C}$ in sequence in wet $\mathrm{O}_{2}$ flow $\left(p \mathrm{H}_{2} \mathrm{O}=0.03 \mathrm{~atm}\right)$. We tried to directly hydrate the pellets with such large size at $600^{\circ} \mathrm{C}$, but they broke up due to the large difference in lattice volume expansion ${ }^{24}$ induced by different hydration rate at surface and inside the pellets. Therefore the hydration was started at $800^{\circ} \mathrm{C}$ where the water solubility is lower and the diffusion is faster than at $600^{\circ} \mathrm{C}$, and decreased to 700 and $600^{\circ} \mathrm{C}$ in sequence. Each temperature was kept for $24 \mathrm{~h}$. After that, the other side of the pellets was etched by phosphoric acid for $30 \mathrm{~min}$, and $\mathrm{Pd}$ was deposited by electroless-plating. ${ }^{11}$ Finally, Ag was pasted in the middle of the side surface of the electrolyte as a reference electrode. The photographs of each electrode of the cell are shown in Fig. 1.

Electrochemical measurement.- A schematic view of the cell, gas flow and electrical connection is shown in Fig. 2a. The cell was sandwiched by alumina rings and an inconel cell holder. Zirconia cement (SUMICERAM S-301, Asahi Chemical) was used to fix the cell in the alumina rings, and also plays the role as an insulator. One type of Ag paste (DD-9301-06, Kyoto Elex), which becomes porous when heat-treated at $600^{\circ} \mathrm{C}$, was painted on the cathode as a current collector. Another type of Ag paste (DD-1240, Kyoto Elex), which becomes dense when heat-treated at $600^{\circ} \mathrm{C}$, was used as a gas sealant and also a current conductor (necessary area other than the cathode). SEM images of the both types of Ag paste heat-treated at $600^{\circ} \mathrm{C}$ are shown in Fig. 2b. Fig. 2c shows a DC equivalent circuit for the cell simulation. Internal resistance of the cell is composed of polarization resistance of cathode $\left(R_{\text {Cathode }}\right)$ and anode $\left(R_{\text {Anode }}\right)$, and 
(a) Cathode side

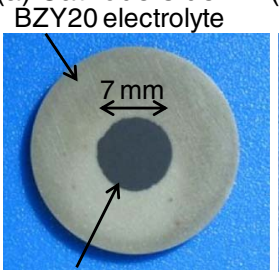

LSCF cathode (b) Anode side

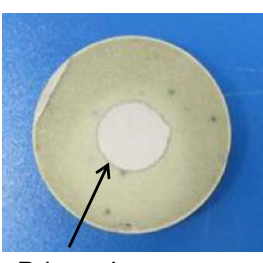

Pdanode (c) Side view

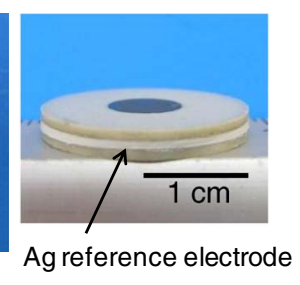

Figure 1. Pictures of the cell fabricated for the electrochemical measurements, showing (a) LSCF cathode side, (b) Pd anode side of the cell, and (c) the side view for the silver reference electrode locating at the middle of the side surface of the BZY20 electrolyte.

ohmic resistance $\left(R_{\text {ohm }}\right)$ including contributions from electrolyte, lead wire and so on. $R_{\mathrm{ohm}}$ is divided into two parts belonging to cathode side $\left(R_{\mathrm{C}, \mathrm{ohm}}\right)$ and anode side $\left(R_{\mathrm{A}, \mathrm{ohm}}\right)$ by reference electrode. $\eta_{\mathrm{a}}$ and $\eta_{\mathrm{c}}$ are defined as overpotential of anode and cathode, respectively.

Electrochemical measurements were carried out at $600^{\circ} \mathrm{C} . \mathrm{H}_{2}$ and $\mathrm{O}_{2}$, both with $0.05 \mathrm{~atm}$ partial pressure of water vapor, were supplied to the anode and cathode sides by $200 \mathrm{sccm}$, respectively. The reference electrode was exposed to the same atmosphere as the cathode. Galvanostatic measurements were carried out by varying current density from 0 to $250 \mathrm{mAcm}^{-2}$ using an external current source (Solartron $1287)$. Potentials of anode to cathode $\left(V_{\text {cell }}\right)$, anode to reference $\left(V_{\mathrm{A}}\right)$ and cathode to reference $\left(V_{\mathrm{C}}\right)$ were collected at each current density level for $120 \mathrm{~s}$. AC impedance measurements were carried out to determine ohmic resistance between each two electrodes in the three electrode system using a combination of the external current source (Solartron 1287) and a frequency response analyzer (Solartron 1260). AC impedance spectra were measured by applying $1 \mathrm{~mA}$ AC current in the frequency range of $1 \mathrm{MHz}$ to $0.01 \mathrm{~Hz}$ under the DC current density of $0-250 \mathrm{mAcm}^{-2}$.

(a)

(c)
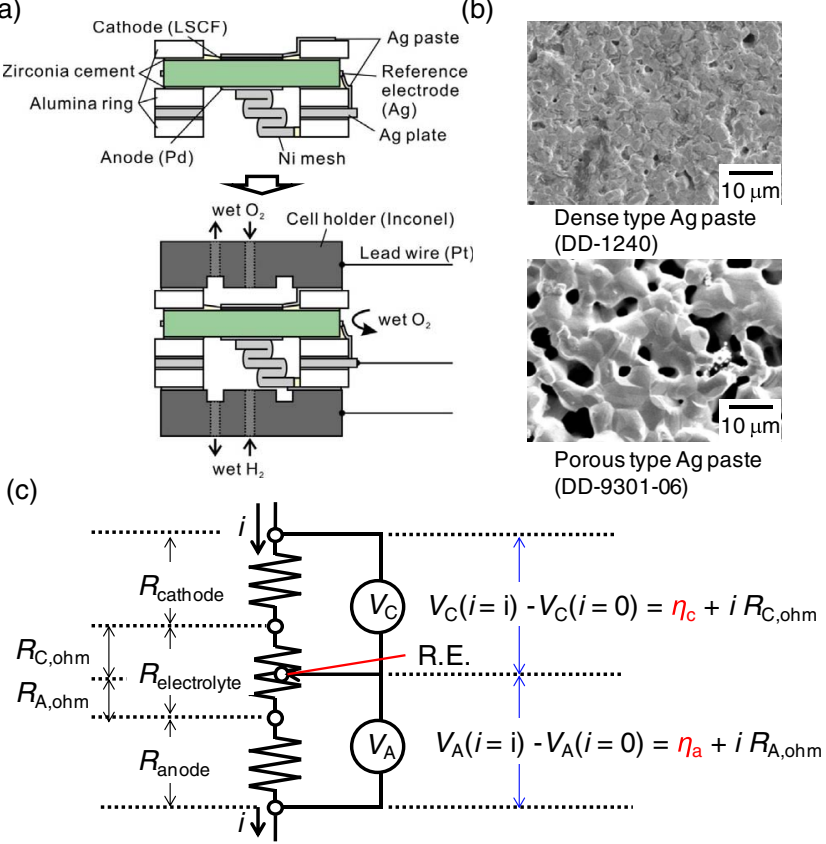

Figure 2. (a) A schematic view of the setting of the cell for the electrochemical measurements, (b) SEM images of two types of $\mathrm{Ag}$ paste sintered at $600^{\circ} \mathrm{C}$, and (c) an equivalent circuit to simulate such cell setting. The atmospheres for the cathode and reference electrode were wet $\mathrm{O}_{2}$. The anode was exposed to wet $\mathrm{H}_{2}$. In all the atmospheres, the partial pressure of water vapor was $0.05 \mathrm{~atm}$.

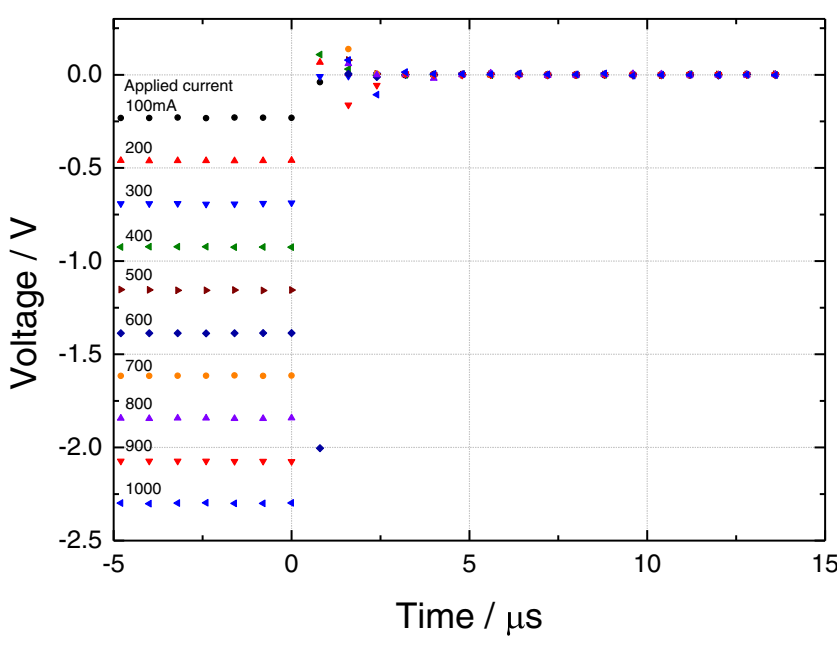

Figure 3. Results of current interruption measurements performed at room temperature using a metal resistor ( $\mathrm{Ni}-\mathrm{Cr}$ alloy wire) to confirm the validity of such method. DC current of $100-1000 \mathrm{~mA}$ was applied for $10 \mathrm{~s}$ before the current interruption.

The current interruption method was used to evaluate the ohmic resistances and overpotentials of the cell. DC current density of $0-250 \mathrm{mAcm}^{-2}$ were applied before the current interruption. The relaxation of potentials between electrodes were collected by multifunction data acquisition module (NI USB-6251) with the sampling rate of $1.25 \mathrm{MHz}$. Fig. 3 shows a result of current interruption measurement of metal resistor (Ni-Cr alloy wire) at room temperature. Since the sample is metal with extremely small capacitance, voltage should become $0 \mathrm{~V}$ just after the current interruption. However, transient behavior or spike appeared in the profile of voltage-time curve in $2 \mu \mathrm{s}$ after current interruption, which is considered to be attributed to an instrumental factor (delay of current interruption, inductance of lead wire, etc.). Therefore the data obtained at elapsed time less than $2 \mu \mathrm{s}$ were ignored when fitting the relaxation curve of voltage.

\section{Results and Discussion}

Galvanostatic and AC impedance measurements.- Fig. 4 shows typical results obtained by the galvanostatic measurement. Open circuit voltage of the cell was $1.077 \mathrm{~V}$, which was close to the theoretical value $(1.145 \mathrm{~V})$, indicating a good gas sealing for the cell and also negligibly small transport number for the charge carriers other than ions (such as electrons and holes) in the electrolyte. It can be seen that $V_{\text {Cell }}$ and $V_{\mathrm{C}}$ decrease, and $V_{\mathrm{A}}$ increases with the increasing current density monotonically.

Since the voltage difference measured between the cathode/anode and reference electrode is composed of the corresponding electrode overpotential and the IR loss (potential drop due to ohmic resistance), the electrode overpotential can be determined by subtracting the IR loss from the measured voltage. We therefore performed AC impedance measurements to determine the IR loss. Some representative spectra are shown in Fig. 5. In the spectrum measured between the anode and reference electrode (Fig. 5a) under the open circuit condition (DC current of $0 \mathrm{mAcm}^{-2}$ ), low frequency region of the spectrum can be fitted by an equivalent circuit composed of a resistance and a constant phase element in parallel. The capacitance is $5.4 \times 10^{-6} \mathrm{~F}$, which is a typical value for the contribution from electrode reaction. Then, $R_{\mathrm{A}, \mathrm{ohm}}$ is estimated to be $15.3 \Omega$ from the left intercept of the arc. However, the case between the cathode and reference electrode is relatively complicated, since as shown in Fig. 5b, two semicircles with flattened appearance can be observed in both the high (100000$100 \mathrm{~Hz})$ and low $(100-0.01 \mathrm{~Hz})$ frequency regions. Finding a proper equivalent circuit to simulate such spectrum is quite difficult, but empirically, the intercept at the high frequency region generally indicates 


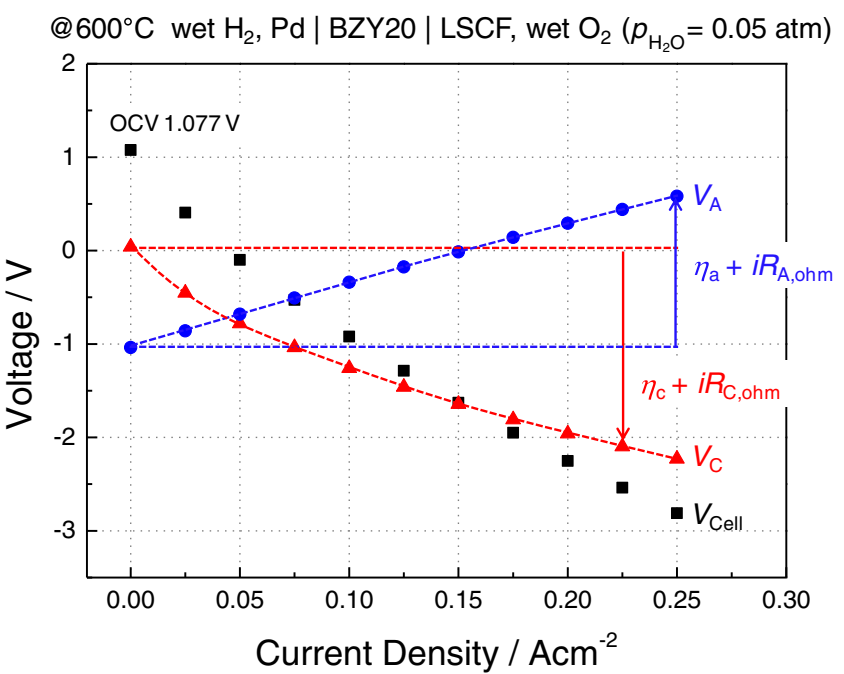

Figure 4. Voltage measured between the cathode and the anode $\left(V_{\mathrm{Cell}}\right)$, and those of the cathode $\left(V_{\mathrm{C}}\right)$, and anode $\left(V_{\mathrm{A}}\right)$ with respect to the reference electrode at $600^{\circ} \mathrm{C}$. The cell was constructed by applying Pd and LSCF to the BZY20 electrolyte as the anode and cathode, respectively. Wet $\mathrm{H}_{2}$ and wet $\mathrm{O}_{2}$ were supplied to the anode and cathode, respectively. The reference electrode was exposed to wet $\mathrm{O}_{2}$. The partial pressure of water vapor in all the atmospheres was $0.05 \mathrm{~atm}$. During the measurements, current density was varied from 0 to $250 \mathrm{mAcm}^{-2}$.

(a) Anode - Reference electrode

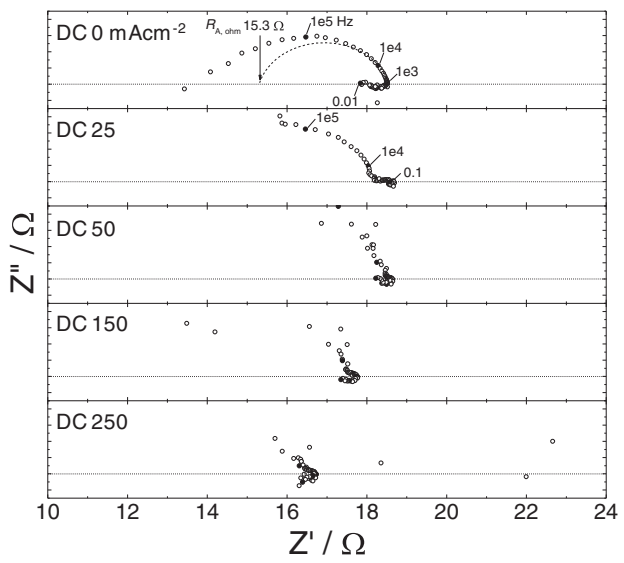

(c) Cathode - Anode

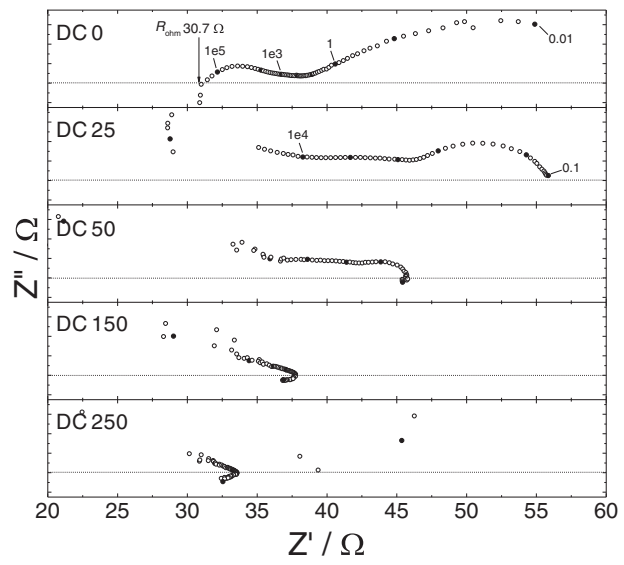

the ohmic resistance. ${ }^{18,25,26}$ Under the open circuit condition (DC current of $\left.0 \mathrm{mAcm}^{-2}\right)$, the ohmic resistance between the cathode and reference electrode $\left(R_{\mathrm{C}, \text { ohm }}\right)$ is thereby estimated to $15.4 \Omega$. Similarly, as shown in Fig. 5c, the ohmic resistance between the cathode and anode is estimated to be $30.7 \Omega$, which just equals the sum of those estimated from the spectra obtained between cathode/anode and the reference electrode, as expected. However, reasonable interpretation is quite difficult when DC current is applied, since the semicircle became unclear (Fig. 5a), and the intercept at the high frequency region $(>10000 \mathrm{~Hz}$ ) disappeared (Fig. 5b and 5c). So, it is necessary to find another way to determine the ohmic resistances under DC current, hence current interruption method is adopted.

Current interruption measurement.- Fig. 6 shows a typical result of current interruption measurement to explain how the data were analyzed. The step of voltage just after the current interruption is attributed to IR loss and the following relaxation part is attributed to overpotential of electrode. The change of voltage was fitted by the equation composed of two different time constants.

$$
V=V_{0}+V_{1} \cdot \exp \left(-t / \tau_{1}\right)+V_{2} \cdot \exp \left(-t / \tau_{2}\right)
$$

$V_{0}, V_{1}, V_{2}$ : constants with the dimension of volt; $\tau_{1}, \tau_{2}$ : time constant which characterize the relaxation of voltage

Fitting was carried out using the data between the elapsed time $t=2.4$ and $160 \mu \mathrm{s}$ as there are unreliable data (spike or deviation from smooth curve) at $t<2.4 \mu \mathrm{s}$. In a precise sense, the current was interrupted at the time between $t=0$ and $0.8 \mu$ s (the last point

\section{(b) Cathode - Reference electrode}

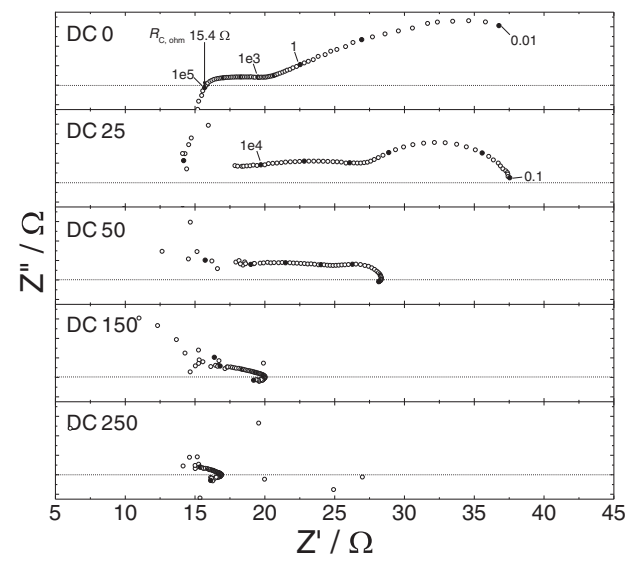




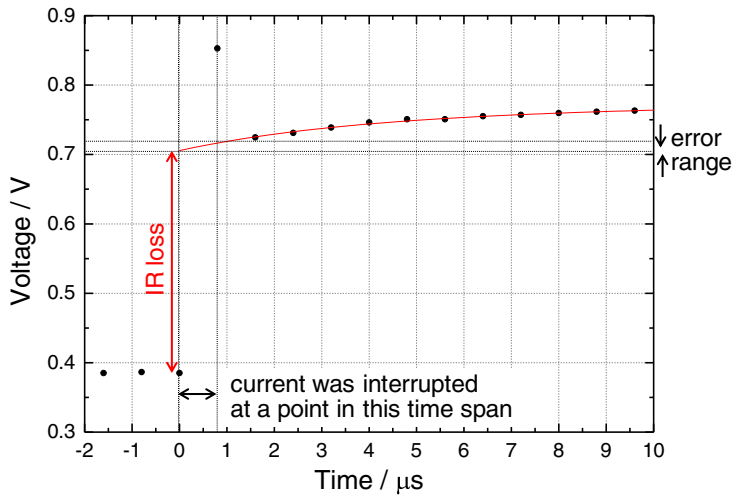

Figure 6. Representative result by using the current interruption method to measure the variation of the voltage between the cathode and anode against the elapsed time at $600^{\circ} \mathrm{C}$. The direct current density of $25 \mathrm{mAcm}^{-2}$ was applied for 60 seconds before the current interruption. Fitted curve with eq. 1 is plotted by a solid line. The cell was constructed by applying Pd and LSCF to the BZY20 electrolyte as the anode and cathode, respectively. Wet $\mathrm{H}_{2}$ and wet $\mathrm{O}_{2}$ were supplied to the anode and cathode, respectively. The reference electrode was exposed to wet $\mathrm{O}_{2}$. The partial pressure of water vapor in all the atmospheres was $0.05 \mathrm{~atm}$. before the current interruption and the next one). Therefore the fitting curve was extrapolated to that time range to evaluate the value of IR loss with error range. Fig. 7 shows the results of current interruption measurements with various DC current of $25-250 \mathrm{mAcm}^{-2}$. The variation of the voltage between each two electrodes was fitted by Eq. 1. Table I shows the parameters in the fitting equation, IR loss and overpotentials obtained by fitting the results of the current interruption measurements. The derived ohmic resistances and overpotentials are plotted against current density in Fig. 8. As shown in Fig. 8a, $R_{\text {ohm }}$ and $R_{\mathrm{C}, \mathrm{ohm}}$ under the DC current flow decrease gradually with the increasing current density. The reason of such phenomenon is discussed later. The overpotential of cathode and anode exhibited non-linear curve against current density and fitted by Tafel equation as shown in Fig. 8b. Overpotential of cathode is about one order higher than that of anode, which indicates clearly that high cathode overpotential is a significant problem in this cell.

Cause of change in electrolyte resistance against current density.As shown in Fig. 8a, $R_{\mathrm{ohm}}$ and $R_{\mathrm{C}, \mathrm{ohm}}$ under DC current flow are different from those under open circuit condition and decrease gradually with the increasing current density. This result indicates that it is inappropriate to calculate overpotentials under DC current using ohmic resistance measured under an open circuit condition. (a) Cathode - Anode

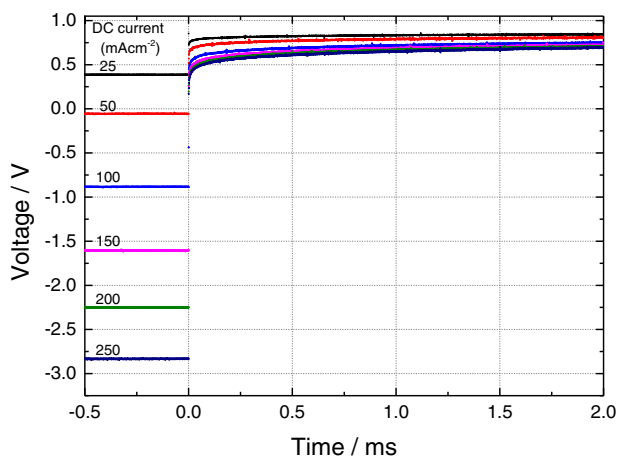

(c) Cathode - Reference

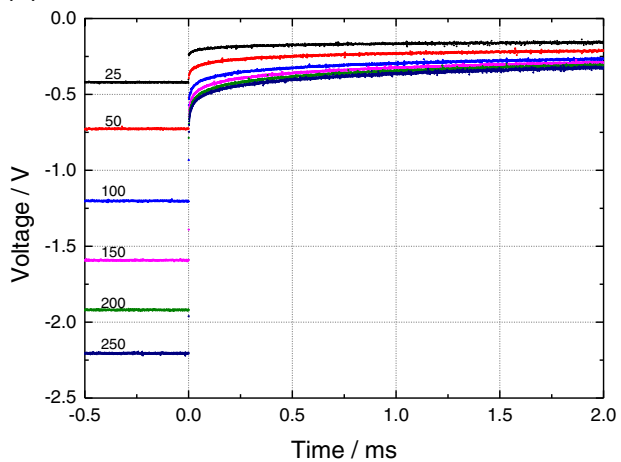

(e) Anode-Reference

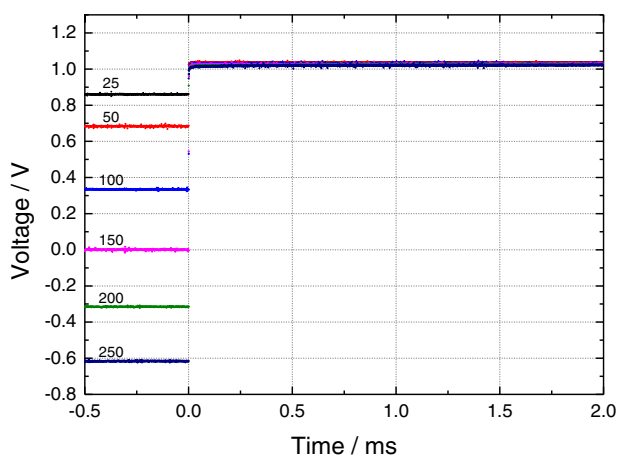

(b) Cathode - Anode

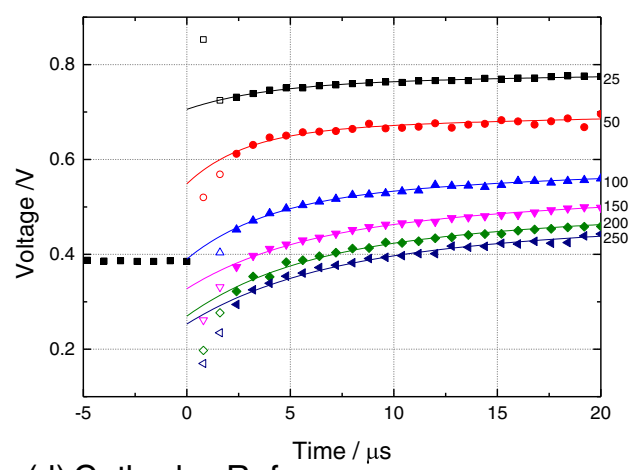

(d) Cathode-Reference

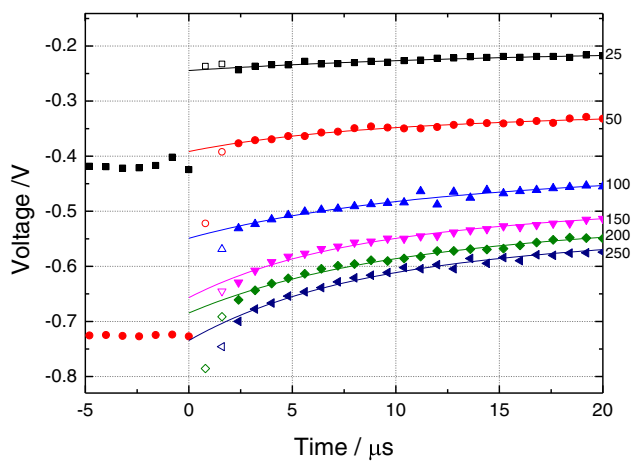

(f) Anode - Reference

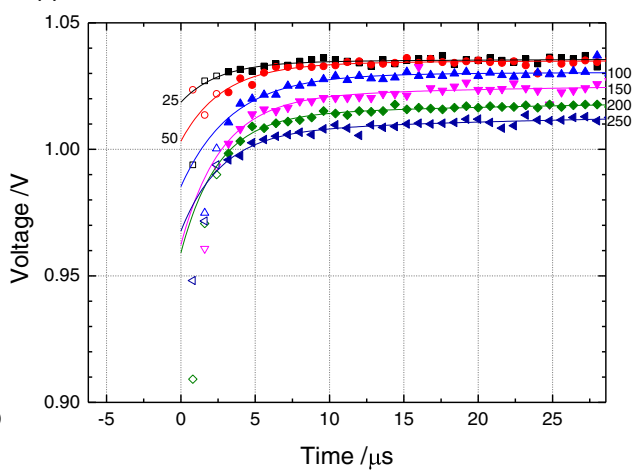

Figure 7. Variation of the voltage between the cathode and anode ((a) \& (b)), cathode and reference electrode ((c) \& (d)), and anode and reference electrode ((e) \& (f)) against the elapsed time at $600^{\circ} \mathrm{C}$, measured by current interruption method. Fitted curve with eq. 1 is plotted in graph (c), (e) and (f). Open symbols represent the points ignored in fitting. The cell was constructed by applying Pd and LSCF to the BZY20 electrolyte as the anode and cathode, respectively. Wet $\mathrm{H}_{2}$ and wet $\mathrm{O}_{2}$ were supplied to the anode and cathode, respectively. The reference electrode was exposed to wet $\mathrm{O}_{2}$. The partial pressure of water vapor in all the atmospheres was $0.05 \mathrm{~atm}$. The direct current density of $25-250 \mathrm{mAcm}^{-2}$ was applied for 60 seconds before the current interruption. 
Table I. Parameters obtained by fitting the results of current interruption measured between (a) cathode and anode, (b) cathode and reference electrode, and (c) anode and reference electrode using Eq. 1.

(a) Cathode - Anode

\begin{tabular}{ccccccrrr}
$i / \mathrm{Acm}^{-2}$ & $V_{0} / \mathrm{V}$ & $V_{1} / \mathrm{V}$ & $\tau_{1} / \mu \mathrm{s}$ & $V_{2} / \mathrm{V}$ & $\tau_{2} / \mu \mathrm{s}$ & $\mathrm{IR}$ loss $/ \mathrm{V}$ & $R_{\text {ohm }} / \Omega$ \\
\hline 25 & 0.806 & -0.054 & 3.9 & -0.045 & 51.9 & 0.32 & 31.9 \\
50 & 0.745 & -0.114 & 2.9 & -0.082 & 61.9 & 0.61 & 30.3 \\
75 & 0.690 & -0.095 & 5.1 & -0.100 & 69.0 & 0.98 & 32.7 \\
100 & 0.645 & -0.134 & 4.0 & -0.120 & 55.8 & 1.27 & 0.52 \\
125 & 0.625 & -0.122 & 5.1 & -0.134 & 62.8 & 1.62 & 31.9 \\
150 & 0.606 & -0.136 & 5.4 & -0.143 & 62.0 & 1.93 & 32.5 \\
175 & 0.596 & -0.144 & 6.1 & -0.147 & 71.0 & 2.24 & 32.2 \\
200 & 0.579 & -0.157 & 5.4 & -0.153 & 65.4 & 2.52 & 32.0 \\
225 & 0.568 & -0.159 & 5.4 & -0.159 & 65.2 & 2.80 & 31.5 \\
250 & 0.563 & -0.154 & 6.1 & -0.155 & 73.5 & 3.09 & 0.74 \\
\hline
\end{tabular}

(b) Cathode - Reference electrode

\begin{tabular}{|c|c|c|c|c|c|c|c|c|}
\hline$i / \mathrm{Acm}^{-2}$ & $V_{0} / \mathrm{V}$ & $V_{1} / \mathrm{V}$ & $\tau_{1} / \mu \mathrm{s}$ & $V_{2} / \mathrm{V}$ & $\tau_{2} / \mu \mathrm{s}$ & IR loss / V & $R_{\mathrm{C}, \mathrm{ohm}} / \Omega$ & $\eta / \mathrm{V}$ \\
\hline 25 & -0.181 & -0.027 & 12.6 & -0.036 & 119.9 & 0.18 & 17.6 & 0.28 \\
\hline 50 & -0.270 & -0.044 & 6.6 & -0.077 & 79.0 & 0.33 & 16.7 & 0.43 \\
\hline 75 & -0.322 & -0.060 & 7.6 & -0.100 & 79.4 & 0.50 & 16.5 & 0.52 \\
\hline 100 & -0.359 & -0.080 & 9.1 & -0.109 & 80.2 & 0.65 & 16.3 & 0.59 \\
\hline 125 & -0.386 & -0.103 & 6.5 & -0.131 & 68.5 & 0.79 & 15.7 & 0.66 \\
\hline 150 & -0.405 & -0.113 & 6.5 & -0.139 & 67.3 & 0.93 & 15.6 & 0.69 \\
\hline 175 & -0.410 & -0.121 & 7.2 & -0.148 & 77.7 & 1.08 & 15.5 & 0.72 \\
\hline 200 & -0.424 & -0.117 & 8.2 & -0.144 & 82.9 & 1.24 & 15.4 & 0.72 \\
\hline 225 & -0.437 & -0.122 & 6.7 & -0.154 & 76.6 & 1.35 & 15.0 & 0.75 \\
\hline 250 & -0.446 & -0.141 & 7.2 & -0.148 & 80.8 & 1.47 & 14.7 & 0.77 \\
\hline
\end{tabular}

(c) Anode - Reference electrode

\begin{tabular}{|c|c|c|c|c|c|c|c|c|}
\hline$i / \mathrm{Acm}^{-2}$ & $V_{0} / \mathrm{V}$ & $V_{1} / \mathrm{V}$ & $\tau_{1} / \mu \mathrm{s}$ & $V_{2} / \mathrm{V}$ & $\tau_{2} / \mu s$ & IR loss / V & $R_{\mathrm{A}, \mathrm{ohm}} / \Omega$ & $\eta / \mathrm{V}$ \\
\hline 25 & 1.036 & -0.016 & 2.5 & -0.002 & 35.0 & 0.16 & 15.8 & 0.018 \\
\hline 50 & 1.035 & -0.030 & 2.8 & -0.002 & 12.4 & 0.32 & 16.0 & 0.034 \\
\hline 75 & 1.033 & -0.028 & 2.5 & -0.007 & 12.5 & 0.49 & 16.4 & 0.038 \\
\hline 100 & 1.031 & -0.044 & 3.4 & -0.002 & 59.1 & 0.64 & 16.0 & 0.052 \\
\hline 125 & 1.029 & -0.060 & 2.9 & -0.004 & 44.7 & 0.80 & 16.0 & 0.071 \\
\hline 150 & 1.026 & -0.057 & 2.7 & -0.006 & 19.9 & 0.96 & 16.0 & 0.075 \\
\hline 175 & 1.025 & -0.052 & 2.9 & -0.006 & 55.7 & 1.13 & 16.1 & 0.071 \\
\hline 200 & 1.021 & -0.054 & 2.5 & -0.008 & 35.4 & 1.27 & 15.9 & 0.078 \\
\hline 225 & 1.022 & -0.040 & 3.2 & -0.009 & 118.4 & 1.44 & 16.0 & 0.064 \\
\hline 250 & 1.016 & -0.039 & 2.7 & -0.009 & 33.0 & 1.58 & 15.8 & 0.069 \\
\hline
\end{tabular}

One possible reason might be temperature rise of the cell with electric current. To examine such possibility, current interruption measurement was carried out after keeping the cell for different time $(5$, $20,60$, and $180 \mathrm{~s})$ under a DC current density $\left(25 \mathrm{mAcm}^{-2}\right)$ application. If the electric current causes the rise of the cell temperature, the temperature should elevate with the elapsed time, accompanied with increased proton conductivity in the electrolyte. However, the IR loss was almost constant as shown in Fig. 9, and the temperature rise is not the reason.

Another possible reason is the change of current distribution in electrolyte. To examine the current distribution, the change of electric potential distribution in electrolyte was calculated by a finite element method. ${ }^{27}$ Fig. 10a represents the schematic view of the cell used in electrochemical measurements. The cross-section of the electrolyte is divided into $50 \times 15$ cells as shown in Fig. 10b. Here, the cells are represented as cell $(x, y)$ using radial position $x$ and vertical position $y$. In this framework the cathode and the anode are contacted to the cell $(1,1) \sim \operatorname{cell}(18,1)$ and $\operatorname{cell}(1,15) \sim \operatorname{cell}(18,15)$, respectively. Electric potential in cathode, anode and cell $(x, y)$ are represented by $\phi_{C}, \phi_{\mathrm{A}}$ and $\phi_{e l}(x, y)$, respectively. Current density between cell $(x$, $y$ ) and the adjacent cells are represented by $i_{t o p}(x, y), i_{\text {left }}(x, y)$, $i_{\text {right }}(x, y)$ and $i_{\text {bottom }}(x, y)$, as shown in Fig. 10c, respectively. When the electric potential of cathode against anode is changed from open circuit voltage $\left(V_{\mathrm{OCV}}=1.072 \mathrm{~V}\right)$ to $V_{\text {cell }}$, the distribution of electric potential and current in electrolyte are obtained by the following procedure.

The ionic current of proton in electrolyte is determined by the gradient of electrochemical potential of proton, $\tilde{\mu}_{\mathrm{H}^{+}}(x, y)$. Assuming that the chemical potential of proton is constant in electrolyte regardless of the applied voltage and position in the electrolyte, the gradient of $\tilde{\mu}_{\mathrm{H}^{+}}(x, y)$ is equal to the gradient of the product of Faraday constant (F) and electric potential, $\phi_{e l}(x, y)$. Therefore the ionic current density of proton between cell $(x, y)$ and the adjacent cells are represented as

$$
\begin{gathered}
i_{\text {top }}(x, y)=-\frac{\sigma}{\mathrm{F}} \cdot \frac{\partial \tilde{\mu}_{\mathrm{H}^{+}}}{\partial y}=-\sigma \cdot \frac{\partial \phi_{\mathrm{el}}}{\partial y} \\
=-\sigma \cdot \frac{\phi_{\mathrm{el}}(x, y)-\phi_{\mathrm{el}}(x, y-1)}{d} \quad \text { at } y>1 \\
i_{\text {bottom }}(x, y)=-\sigma \cdot \frac{\phi_{e l}(x, y+1)-\phi_{e l}(x, y)}{d} \quad \text { at } y<15 \\
i_{\text {left }}(x, y)=-\sigma \cdot \frac{\phi_{e l}(x, y)-\phi_{e l}(x-1, y)}{d} \quad \text { at } x>1 \\
i_{\text {right }}(x, y)=-\sigma \cdot \frac{\phi_{e l}(x+1, y)-\phi_{e l}(x, y)}{d} \quad \text { at } x<50
\end{gathered}
$$

where $\sigma$ is the protonic conductivity of electrolyte and $d$ is the distance between cells.

Boundary conditions are described as below.

$$
\begin{gathered}
i_{\text {left }}(1, y)=0 \quad \text { (axial symmetry of electrolyte) } \\
i_{\text {top }}(x, 1)=0 \quad \text { at } \quad x>18 \quad \text { (electrolyte/gas interface) } \\
i_{\text {bottom }}(x, 15)=0 \quad \text { at } x>18 \quad \text { (electrolyte/gas interface) }
\end{gathered}
$$


(a) Ohmic resistance

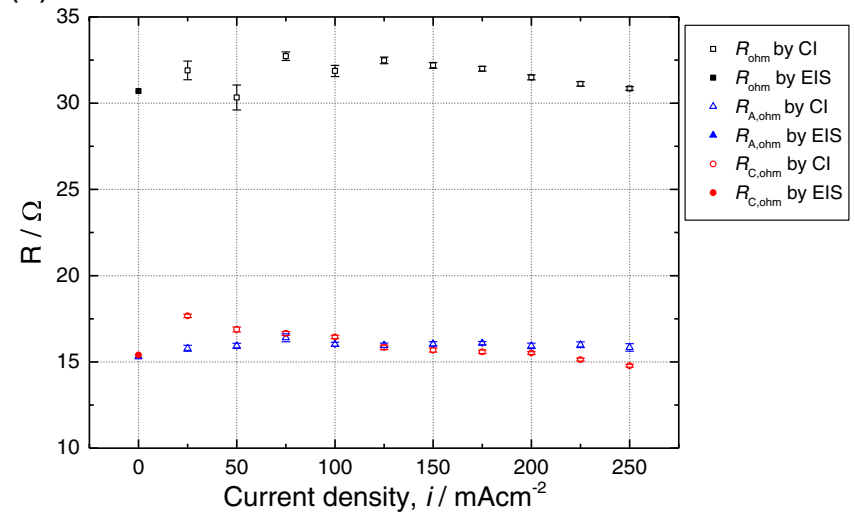

(b) Overpotential

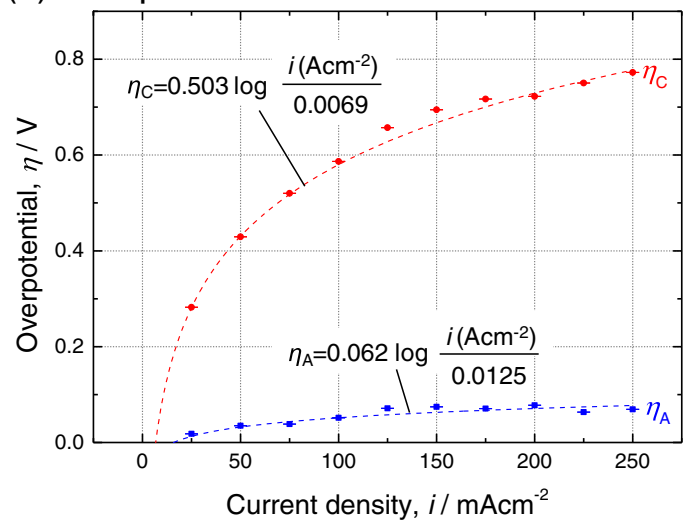

Figure 8. (a) ohmic resistances and (b) overpotentials against current density determined by the current interruption method at $600^{\circ} \mathrm{C}$. In Fig. 8 (a) the data obtained by the A. C. impedance measurements (EIS) at the open circuit condition are adopted to represent the resistances at the current density of $0 \mathrm{mAcm}^{-2}$. The dashed line in Fig. 8(b) represents the fitting results by Tafel equation. The cell was constructed by applying Pd and LSCF to the BZY20 electrolyte as the anode and cathode, respectively. Wet $\mathrm{H}_{2}$ and wet $\mathrm{O}_{2}$ were supplied to the anode and cathode, respectively. The reference electrode was exposed to wet $\mathrm{O}_{2}$. The partial pressure of water vapor in all the atmospheres was $0.05 \mathrm{~atm}$

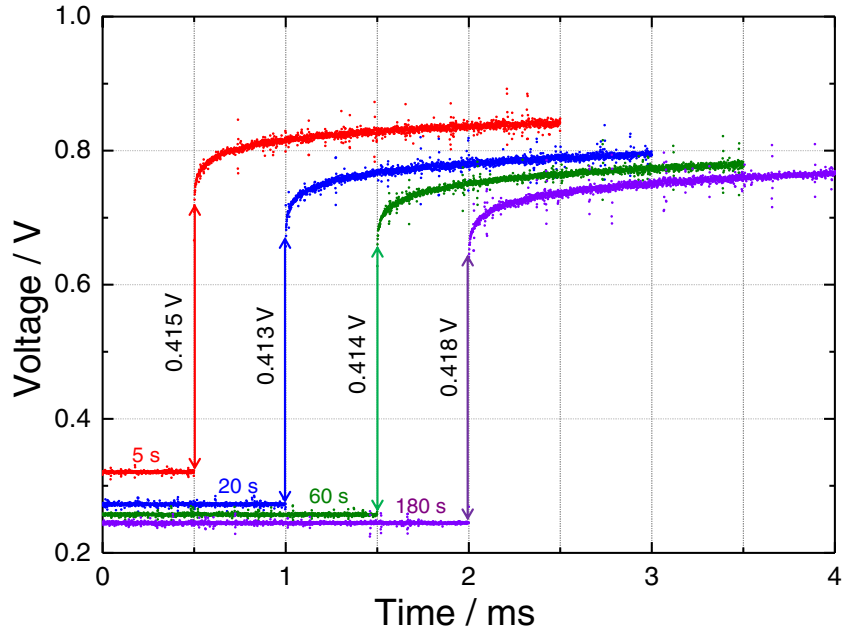

Figure 9. Influence of the time to apply current before current interruption on the result of the measurement. DC current of $25 \mathrm{mAcm}^{-2}$ was applied to the cell for 5 to $180 \mathrm{~s}$, and the voltage between cathode and anode was measured at $600^{\circ} \mathrm{C}$. The cell was constructed by applying Pd and LSCF to the BZY20 electrolyte as the anode and cathode, respectively. Wet $\mathrm{H}_{2}$ and wet $\mathrm{O}_{2}$ were supplied to the anode and cathode, respectively. The reference electrode was exposed to wet $\mathrm{O}_{2}$. The partial pressure of water vapor in all the atmospheres was $0.05 \mathrm{~atm}$.

Current density through the electrode/electrolyte interface is approximated by Tafel equation and the coefficients are obtained by fitting the results in Fig. 8b.

$$
\begin{aligned}
& \eta_{\mathrm{A}}=0.062 \times \log \left(\frac{i}{0.0125}\right) \\
& \eta_{C}=0.503 \times \log \left(\frac{i}{0.0069}\right)
\end{aligned}
$$

Electrode overpotential of anode and cathode at a radial position $x, \eta_{\mathrm{A}}(x)$ and $\eta_{\mathrm{C}}(x)$, are described by the change in the difference of electric potentials in electrode and electrolyte at $V=V_{\mathrm{OCV}}$ and

(a)

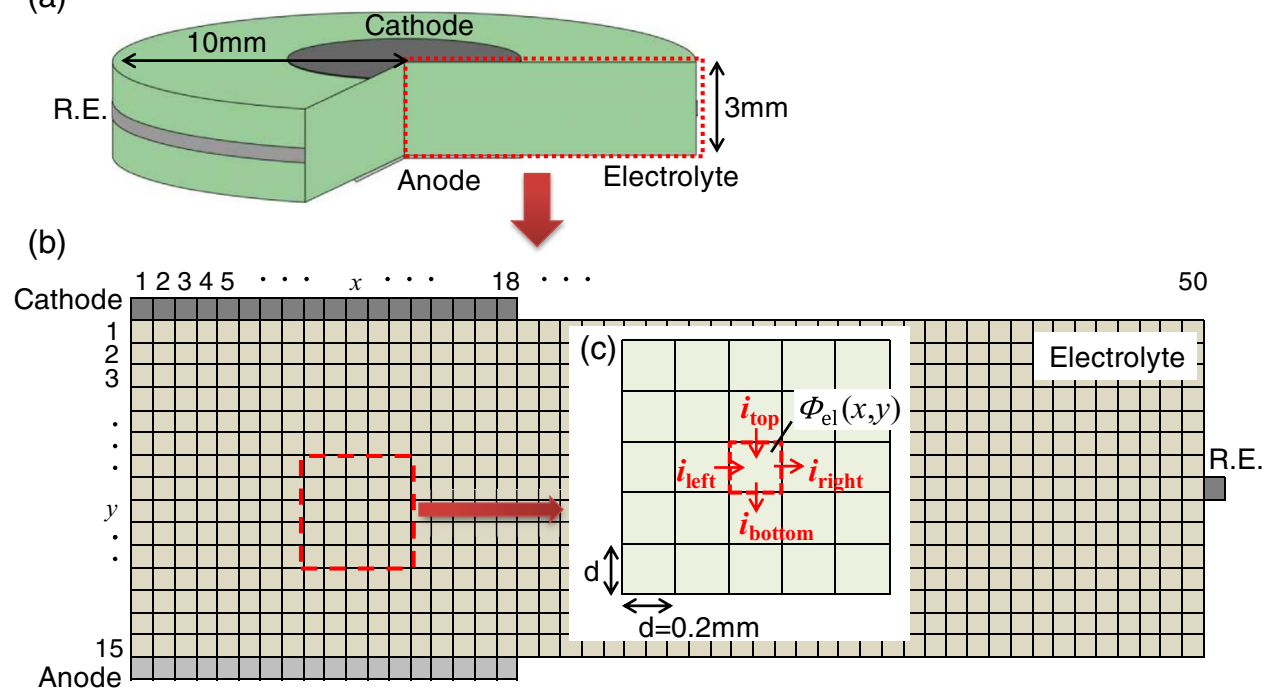

Figure 10. (a) a schematic view of cross-section of the electrolyte, (b) and (c) divided cells in the electrolyte for finite element method. The electrolyte is divided into $50 \times 15$ cells. Cathode and anode is contacted to the cell $(1,1) \sim \operatorname{cell}(18,1)$ and cell $(1,15) \sim$ cell $(18,15)$, respectively. 
(a) $V_{\text {cell }}=0.387 \mathrm{~V}\left(=V_{\text {ocV }}-0.685\right)$

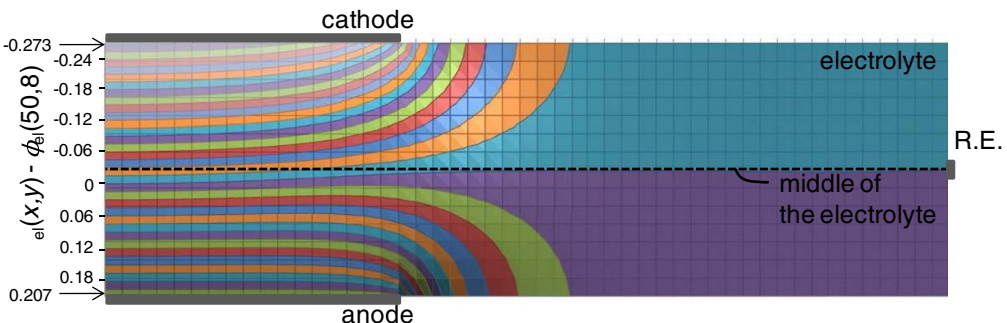

(b) $V_{\text {cell }}=-2.828 \mathrm{~V}\left(=V_{\text {OCV }}-3.9\right)$

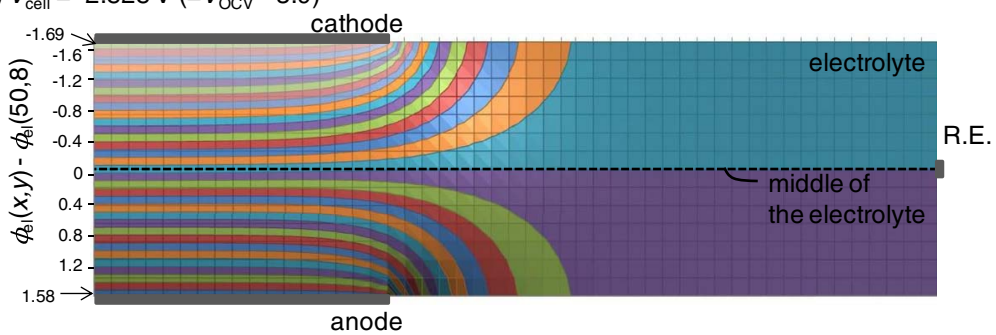

Figure 11. Distribution of electric potential in electrolyte at $V_{\text {cell }}$ $=(\mathrm{a}) 0.387$ and (b) $-2.8 \mathrm{~V}$. The value is given as the difference with that in cell $(50,8)$, the adjacent cell to reference electrode.

$V_{\text {cell }}$ as

$$
\begin{aligned}
\eta_{\mathrm{A}}(x) & =\left(\phi_{\mathrm{A}}-\phi_{\mathrm{el}}(x, 15)\right)-\left(\phi_{\mathrm{A}}^{i=0}-\phi_{\mathrm{el}}^{i=0}(x, 15)\right) \\
& =-\left(\phi(x, 15)-\phi_{\mathrm{A}}-\left(\phi_{\mathrm{el}}^{i=0}(x, 15)-\phi_{\mathrm{A}}^{i=0}\right)\right) \\
& =-(\phi(x, 15)-\Phi)
\end{aligned}
$$

$$
\begin{aligned}
\eta_{\mathrm{C}}(x) & =\left(\phi_{\mathrm{el}}(x, 1)-\phi_{\mathrm{C}}\right)-\left(\phi_{\mathrm{el}}^{i=0}(x, 1)-\phi_{\mathrm{C}}^{i=0}\right) \\
& =\left(\phi_{\mathrm{el}}(x, 1)-\left(\phi_{\mathrm{A}}+V_{\mathrm{cell}}\right)\right)-\left(\phi_{\mathrm{el}}^{i=0}(x, 15)-\left(\phi_{\mathrm{A}}^{i=0}+V_{\mathrm{OCV}}\right)\right) \\
& =V_{\mathrm{OCV}}-V_{\text {cell }}+\left(\phi_{\mathrm{el}}(x, 1)-\phi_{\mathrm{A}}-\left(\phi_{\mathrm{el}}^{i=0}(x, 15)-\phi_{\mathrm{A}}^{i=0}\right)\right) \\
& =V_{\mathrm{OCV}}-V_{\text {cell }}+\phi_{\mathrm{el}}(x, 1)-\Phi
\end{aligned}
$$

where $\Phi$ is defined as $\Phi=\phi_{\mathrm{A}}+\left(\phi_{\mathrm{el}}^{i=0}(x, 15)-\phi_{\mathrm{A}}^{i=0}\right)$ and the superscript $i=0$ indicates that the term represents the value at open circuit condition.
Similarly, current density between cells is described by the gradient of $\phi_{e l}(x, y)$ and overpotentials of cathode and anode are described by $\phi(x, y)-\Phi$. Therefore, when the initial value of $\phi(x, y)-\Phi$ is fixed, current density across all interfaces can be calculated. Then, the relaxation of $\phi(x, y)-\Phi$ was carried out to meet the balance of current flow in and out each cell. The calculation was performed using Microsoft Excel 2007.

The derived electric potential distribution at $V_{\text {cell }}=0.387$ and $-2.8 \mathrm{~V}$ are shown in Fig. 11. For clarity, the value is given as the difference with that in cell $(50,8)$, the adjacent cell to reference electrode. It can be seen that the equipotential surface to cell $(50,8)$ in the center of electrolyte, left hand side, is located closer to anode at $V_{\text {cell }}$ $=0.387 \mathrm{~V}$ than at $V_{\text {cell }}=-2.828 \mathrm{~V}$. This shift of equipotential surface indicates the possibility to reduce the proportion of $R_{\mathrm{C} \text {,ohm }}$ to $R_{\mathrm{A} \text {,ohm }}$ when $V_{\text {cell }}$ changed from 0.387 to $-2.8 \mathrm{~V}$.

Distribution of normalized current density at $V_{\text {cell }}=0.387$ and $-2.8 \mathrm{~V}$ are shown in Fig. 12. The value is normalized as the average current density on electrode/electrolyte interface becomes one. It can

(a) $V_{\text {cell }}=0.387 \mathrm{~V}\left(=V_{\text {ocV }}-0.685\right)$

cathode

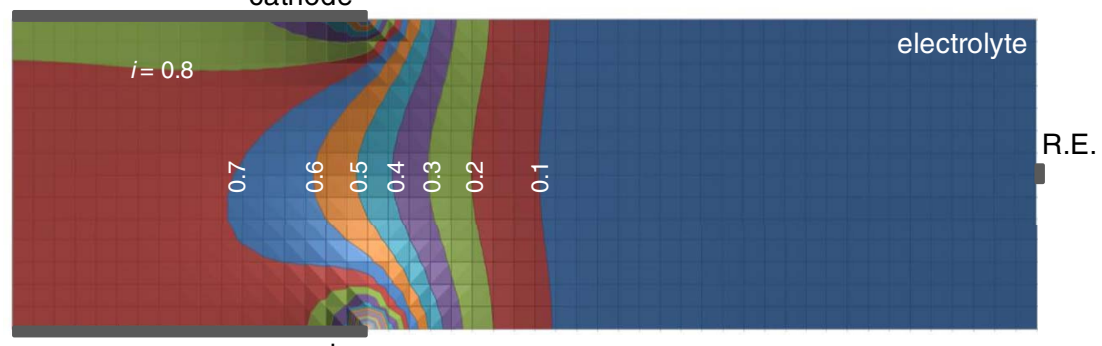

anode

Figure 12. Distribution of normalized current density in the electrolyte at $V_{\text {cell }}=$ (a) 0.387 and (b) $-2.8 \mathrm{~V}$. The value of current density is normalized as the average current density on electrode/electrolyte interface

(b) $V_{\text {cell }}=-2.828 \mathrm{~V}\left(=V_{\text {OCV }}-3.9\right)$ cathode

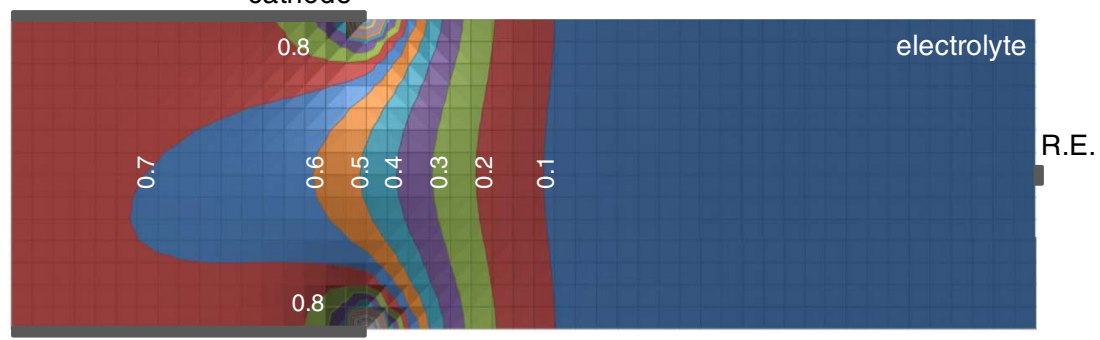
becomes one. 


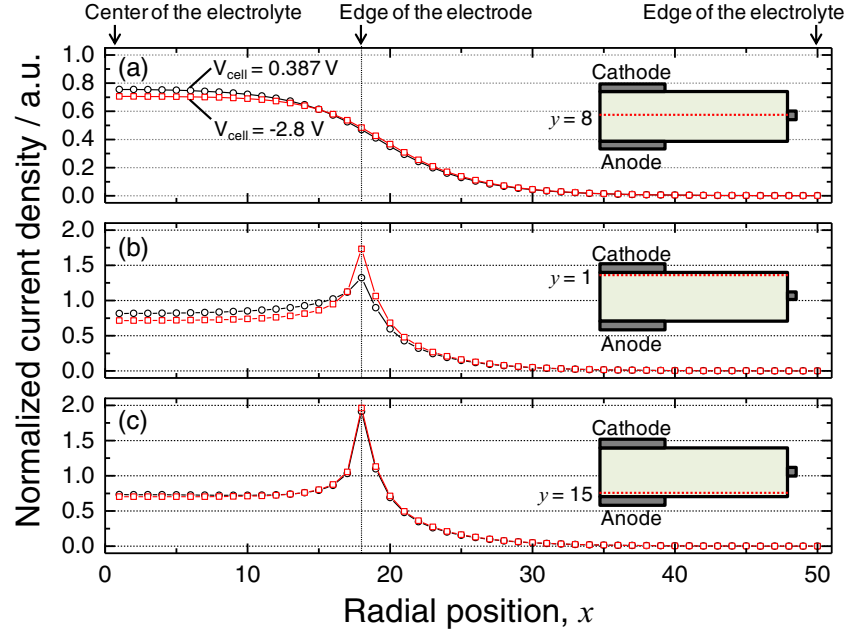

Figure 13. Distribution of normalized current density in cross-section of the electrolyte at (a) $y=8$ (in the middle of the electrolyte), (b) $y=1$ (cathode side) and (c) $\mathrm{y}=15$ (anode side) at $V_{\text {cell }}=0.387$ and $-2.8 \mathrm{~V}$. The value of current density is normalized as the average current density on electrode/electrolyte interface becomes one.

be seen that the current concentrates at the edge of the electrodes and flows not only between cathode and anode $(x<18)$ but also in the external part of the electrolyte $(x>18)$. For detail analysis of the influence of applied voltage, distribution of normalized current density in cross-section of the electrolyte is plotted against radial position in Fig. 13. As shown in Fig. 13a, the normalized current density in the middle of the electrolyte decrease at $x<18$ (between cathode and anode) and slightly increase at $x>18$ when a higher voltage is applied. This change in current distribution means that the current pathway in the electrolyte expands to the radial direction and is considered to decrease the ohmic resistance of whole cell, $R_{\mathrm{ohm}}$, when a higher voltage was applied. Comparing the current distribution near the cathode and anode shown in Fig. 13b and 13c, the change of current density against applied voltage is noticeable in cathode side. Normalized current density between cathode and anode $(x<18)$ is clearly decreased in cathode side while that is almost constant in anode side when $V_{\text {cell }}$ is changed from 0.387 to $-2.828 \mathrm{~V}$. This difference is considered to be the cause of the shift of equipotential surface.

As a conclusion, when a higher voltage is applied, the shift of equipotential surface reduces the proportion of $R_{\mathrm{C}, \mathrm{ohm}}$ to $R_{\mathrm{A}, \mathrm{ohm}}$, and the expansion of current pathway to the radial direction in the electrolyte decreases $R_{\mathrm{ohm}}\left(=R_{\mathrm{C}, \mathrm{ohm}}+R_{\mathrm{A}, \mathrm{ohm}}\right)$. The combination of these effects can qualitatively explain the results in Fig. 8a that $R_{\text {ohm }}$ and $R_{\mathrm{C}, \mathrm{ohm}}$ decrease, whereas $R_{\mathrm{A}, \mathrm{ohm}}$ is almost constant with the increasing current density.

\section{Conclusions}

The electrochemical performance of an electrolyte supported cell, Pd (wet $\mathrm{H}_{2}$ ) | BZY20 | LSCF (wet $\mathrm{O}_{2}$ ), was accurately measured at $600^{\circ} \mathrm{C}$ in the three-electrode system. The ohmic resistance of electrolyte under the open circuit condition and DC current flow were evaluated by the $\mathrm{AC}$ impedance and current interruption measurements, respectively. It was found that the ohmic resistances of the whole cell and also the cathode side, which were evaluated by the current interruption method, decreased with the increasing current density. Such phenomenon is considered to be attributed to the change in current distribution in the electrolyte. The overpotentials of the LSCF cathode and Pd anode on the BZY20 electrolyte are $0.587 \mathrm{~V}$ and $0.053 \mathrm{~V}$ at $100 \mathrm{mAcm}^{-2}$, respectively, and exhibited a logarithmic relationship with the current density. The results clearly indicate that the large cathode overpotential is a significant problem restricting the performance of the fuel cell.

\section{References}

1. M. Juhl, S. Primdahl, C. Manon, and M. Mogensen, J. Power Sources, 61, 173 (1996)

2. R. J. Aaberg, R. Tunold, M. Mogensen, R.W. Berg, and R. Ødegárd, J. Electrochem. Soc., 145, 2244 (1998)

3. S. B. Adler, J. Electrochem. Soc., 149, E166 (2002)

4. S. McIntosh, J. M. Vohs, and R. J. Gorte, J. Electrochem. Soc., 150, A1305 (2003).

5. V. V. Krishnan, S. McIntosh, R.J. Gorte, and J. M. Vohs, Solid State Ionics, 166, 191 (2004).

6. S. McIntosh, S. B. Adler, J. M. Vohs, and R. J. Gorte, Electrochem. Solid-State Lett., 7, A111 (2004)

7. S. H. Jensen, A. Hauch, P. V. Hendriksen, M. Mogensen, N. Bonanos, and T. Jacobsen, J. Electrochem. Soc., 154, B1325 (2007).

8. R. Barfod, M. Mogensen, T. Klemens $\emptyset$, A. Hagen, Y. L. Liu, and P. V. Hendriksen, J. Electrochem. Soc., 154, B371 (2007).

9. T. Ramos, J. Hjelm, and M. Mogensen, J. Electrochem. Soc., 158, B814 (2011).

10. T. Ramos, M. Søgaard, and M. B. Mogensen, J. Electrochem. Soc., 161, F434 (2014)

11. Y. Okumura, Y. Nose, J. Katayama, and T. Uda, J. Electrochem. Soc., 158, B1067 (2011).

12. Y. Yamazaki, R. Hernandez-Sanchez, and S. M. Haile, Chem. Mater, 21, 2755 (2009).

13. A. D'Epifanio, E. Fabbri, E. Di Bartolomeo, S. Licoccia, and E. Traversa, Fuel Cells, 8, 69 (2008).

14. S. M. Choi, J. H. Lee, H. I. Ji, K. J. Yoon, J. W. Son, B. K. Kim, H. J. Je, H. W. Lee, and J. H. Lee, Ceram. Int., 39, 9605 (2013).

15. D. Gao and R. Guo, J. Alloys Compd., 493, 288 (2010).

16. I. Luisetto, S. Licoccia, A. D'Epifanio, A. Sanson, E. Mercadelli, and E. Di Bartolomeo, J. Power Sources, 220, 280 (2012).

17. Z. Sun, E. Fabbri, L. Bi, and E. Traversa, Phys. Chem. Chem. Phys., 13, 7692 (2011).

18. R. Mukundan, P. K. Davies, and W. L. Worrell, J. Electrochem. Soc., 148, A82 (2001).

19. Z. Hui and P. Michele, J. Mater. Chem., 12, 3787 (2002).

20. T. Hibino, A. Hashimoto, M. Suzuki, and M. Sano, J. Electrochem. Soc., 149, A1503 (2002).

21. K. Nomura and H. Kageyama, Solid State Ionics, 178, 661 (2007).

22. D. Poetzsch, R. Merkle, and J. Maier, J. Power Sources, 242, 784 (2013).

23. S. Imashuku, T. Uda, Y. Nose, G. Taniguchi, Y. Ito, and Y. Awakura, J. Electrochem. Soc., 156, B1 (2009)

24. C. Hiraiwa, D. Han, A. Kuramitsu, A. Kuwabara, H. Takeuchi, M. Majima, and T. Uda, J. Am. Ceram. Soc., 96, 879 (2013).

25. L. Yang, Z. Liu, S. Wang, Y. Choi, C. Zuo, and M. Liu, J. Power Sources, 195, 471 (2010).

26. W. Sun, Z. Shi, M. Liu, L. Bi, and W. Liu, Adv. Funct. Mater, 24, 5695 (2014).

27. K. A. Sasaki, Y. Hao, and S. M. Haile, Phys. Chem. Chem. Phys., 11, 8349 (2009) 